IZA DP No. 7903

Leadership and the Research Productivity of University Departments

Amanda H. Goodall

John M. McDowell

Larry D. Singell

January 2014 


\title{
Leadership and the Research Productivity of University Departments
}

\author{
Amanda H. Goodall \\ Cass Business School, City University London \\ and IZA \\ John M. McDowell \\ Arizona State University \\ Larry D. Singell \\ University of Indiana Bloomington
}

Discussion Paper No. 7903
January 2014

IZA

P.O. Box 7240

53072 Bonn

Germany

Phone: +49-228-3894-0

Fax: +49-228-3894-180

E-mail: iza@iza.org

\begin{abstract}
Any opinions expressed here are those of the author(s) and not those of IZA. Research published in this series may include views on policy, but the institute itself takes no institutional policy positions. The IZA research network is committed to the IZA Guiding Principles of Research Integrity.

The Institute for the Study of Labor (IZA) in Bonn is a local and virtual international research center and a place of communication between science, politics and business. IZA is an independent nonprofit organization supported by Deutsche Post Foundation. The center is associated with the University of Bonn and offers a stimulating research environment through its international network, workshops and conferences, data service, project support, research visits and doctoral program. IZA engages in (i) original and internationally competitive research in all fields of labor economics, (ii) development of policy concepts, and (iii) dissemination of research results and concepts to the interested public.
\end{abstract}

IZA Discussion Papers often represent preliminary work and are circulated to encourage discussion. Citation of such a paper should account for its provisional character. A revised version may be available directly from the author. 
IZA Discussion Paper No. 7903

January 2014

\section{ABSTRACT}

\section{Leadership and the Research Productivity of University Departments ${ }^{*}$}

Much of human knowledge is produced in the world's university departments. There is little scientific evidence, however, about how those hundreds of thousands of departments are best organized and led. This study hand-collects longitudinal data on departmental chairpersons in 58 US universities over a 15-year period. There is one robust predictor of a department's future research output. After adjustment for a range of personal and institutional characteristics, departmental research productivity improves when the incoming department Chair's publications are highly cited. A one SD increase in citations is associated with a 0.5 SD later rise in departmental productivity. By contrast, the quality-weighted publication record per se of the incoming Chair has no predictive power.

JEL Classification: $\quad$ I12, I23, M51, M54

Keywords: $\quad$ scientific productivity, department chairs, expert leaders

Corresponding author:

Amanda H. Goodall

Department of Management

Cass Business School

City University London

106 Bunhill Row, room 4094

London EC1Y 8TZ

United Kingdom

E-mail: amanda@amandagoodall.com

\footnotetext{
* We would like to thank Dan Hamermesh, Andrew Oswald, and Gerard Pfann for helpful suggestions, and Andrea Lockhart for research assistance.
} 


\section{INTRODUCTION}

The advancement of scientific knowledge is the primary responsibility of approximately 300,000 academic departments housed in more than 20,000 universities worldwide ${ }^{1}$, yet relatively little is known about the factors that determine the productivity of those departments. We provide the first longitudinal evidence consistent with the hypothesis that the characteristics of an incoming chairperson may have an influence upon the subsequent research production of his or her university department. An incoming individual's citations are found to be a strong predictor of later departmental productivity. In contrast, the appointment of a highly-published scholar is in itself not longitudinally predictive of later organizational success. ${ }^{2}$

Chairs (or 'Heads of Department') play a central role in the academic departments that make up universities. They manage daily operations, hire faculty and professional staff, and work closely with senior university administrators, most of whom were themselves once departmental heads. However, because faculty often view the position as a poisoned chalice, these chairpersons can be reluctant leaders, who are selected through moral persuasion and a rotation system that sometimes depends as much on a scholar's age as aptitude for the job (Clotfelter \& Rothschild, 1993; Ehrenberg, 1999).

The aim of this study is to examine the statistical links, in the spirit of Granger causality, between the characteristics of incoming Chairs and the later scientific productivity of their departments. First, data are collected on 169 chairpersons in 58 US university departments over nearly two decades, for one of the largest university disciplines, and one that sits between the mathematical sciences and non-mathematical social sciences, namely, the field of Economics. Second, over the course of several years, measures of subsequent departmental research success

${ }^{1}$ Cybermetrics Lab, Consejo Superior de Investigaciones Científicas (CSIC), Spain.

${ }^{2}$ We caution the reader from the outset that our study is not able to establish causality in the way a randomized controlled trial can (Antonakis, Bendahan, Jacquart \& Lalive, 2010). It is instead in the spirit of the 'prospective' analysis common in medical science. We return to this issue below. 
were carefully collected and checked using diverse websites and extensive hard-copy materials. The dependent variable in the regression equations is the change in Economics departments' research output, after the Chair has been appointed, which is constructed as a measure of the relative improvement in departmental productivity. Several independent variables are controlled for, including institutional variables such as income and federal grants, and Chairs' other characteristics, such as their gender, experience and publications. The results suggest a concave relationship between a Chair's citations and the subsequent department performance.

In the next section of this paper we connect the study with the relevant literature and propose a testable hypothesis. The data and descriptive statistics are presented in Section 3, and the econometric analyses and results follow in Section 4. Finally, in Section 5 we revisit the literature and discuss possible explanations for our results.

\section{BACKGROUND AND HYPOTHESES}

There is a growing research literature on the nature of scientific production and the importance of effective leadership in its success ${ }^{3}$. Recent work suggests that the management of research enterprise has become more complex as modern scientific study is increasingly produced by teams, that have grown in size, are more likely to involve multi-university collaborations, and are ever more geographically dispersed (Adams, Black, Clemmons \& Stephan, 2005; Wuchty, Jones \& Uzzi, 2007; Jones, Wuchty \& Uzzi, 2008). It is not surprising then that management practices, such as rewards and incentives, and research evaluation processes, are found to be associated with the performance of research teams (see Van der Weijden, de Gilder, Groenewegen \& Klasen, 2008). Academic departments frequently house

\footnotetext{
${ }^{3}$ Early studies that modern work builds on includes: Pelz, 1956; Andrews \& Farris, 1967; Blume \& Sinclair, 1973, among others.
} 
many (ever-evolving) research teams and the head of these units must manage a larger, more heterogeneous group of faculty who have a broader mission than pure research.

The role of academic departments, and the Chairs who manage them, is particularly critical in research universities that tend to be decentralised with devolved powers going to departments. Their important function is highlighted in a new study that assesses the effect of management practices on the performance of universities (McCormack, Propper \& Smith, 2013). McCormack, Propper \& Smith (2013) examine management procedures in 112 UK universities using the measure of management quality tool developed by Bloom and Van Reenen (2007). McCormack and colleagues (2013) interview 248 department Chairs in the disciplines of Business, Computer Science, Psychology, and English. They find that the quality of management practices can be directly linked to better performance in both research and teaching. The result holds for all types of universities - research or teaching focused, new or old. Of particular relevance to our study is their finding that it is management practised at the level of academic departments, not by the centralised human resources, which matters most to research and teaching performance.

Beerkens (2013) reports a similar finding in Australian universities that have been subject to increased competition by government since the mid-1990s. She uses a research management index that aggregates a number of management practices at the institutional, school and individual level. She finds that universities with intensive research management systems are associated with greater research productivity.

Our study focuses on leadership. It is related in spirit to earlier longitudinal research on a panel of universities (Goodall, 2006, 2009a,b) that identified a relationship between the research productivity of a university president (over a lifetime) and the research performance of their institution (later decades). The presidents' study -- one that argued for the idea of 'expert 
leaders' -- found that presidents with higher levels of life-time citations were associated with universities that went on to perform the best.

Chairs generally serve at the discretion of a senior manager (e.g. dean, provost, president) and prior work suggests that there is a systematic pattern to who holds the position. For example, department chairs are disproportionately likely to be white and male, although women and minorities have recently been increasing in number (Carroll \& Wolverton, 2004; Conrad, Carr, Knight, Renfrew, Dunn \& Pololi, 2010). It is not unusual for senior administrators to select Chairs who have either undergone a decline in research productivity or made fewer research-specific investments over their careers (McDowell, Singell \& Stater, 2009; McDowell, Singell \& Stater, 2011), although it is less common in Tier 1 research universities that assign greater weight to the research productivity of potential departmental Chairs (Moore, Newman, \& Turnbull. 2003; Ness \& Samet, 2010, Ehrenberg, 1999). Our central research focus can be expressed in the following hypothesis.

Hypothesis: Academic departments led by Chairs who have accomplished research careers are associated with improved research performance.

\section{DAta AND BAsic Statistics}

Data are collected on 169 chairpersons in 58 US economics departments over a fifteenyear period, between 1995 and 2010. The independent variables in the regression equations include career and demographic information about each Chair, and our dependent variable includes measures of subsequent departmental research success. Variable definitions described below and presented in Table 1. 
(INSERT Table 1 HERE)

\subsection{Dependent Variable}

The dependent variable in the model is the change in Economics departments' research output after the Chair has been appointed, which is a measure of the relative improvement in departmental productivity (see Table 1: Variable Definitions). Specifically, departmental research success is calculated as the share of total US weighted Economics publications (i.e. 1/n and quality index) measured between the first year ( $\mathrm{t}=0)$ of the Chair's appointment and the current year t, where research output in year t is measured by a 3-yr moving average in years $\mathrm{t}-1$, $\mathrm{t}$, and $\mathrm{t}+1$. The dependent variable uses publications data (collected annually over the years 1995 through 2010) from 11 of the "most-selective” journals. These include: American Economic Review, Econometrica, Economic Journal, Economica, International Economic Review, Journal of Economic Theory, Journal of Monetary Economics, Journal of Political Economy, Quarterly Journal of Economics, Review of Economics and Statistics, and the Review of Economic Studies. Only data relating to full articles are collected, thus excluding comments, replies and other such shorter forms of communications.

Table 2 presents a ranking of Economics departments over the 15 years (1995-2010) using our dependent variable -- the mean annual research output of total weighted publications authored by individuals with an affiliation in a US Economics department. Six institutions included in Table 2 are not used in the empirical analysis because: a) no Chair was appointed after 1994 for which at least 3 years can be observed (Arizona State University and Ohio State); b) issues related to the availability of our university revenue variable, Integrated Postsecondary Education Data (Dartmouth and Rutgers); and c) there were no clearly delineated Economics departments (Caltech and Cornell). 
(INSERT Table 2 HERE)

\subsection{Independent Variables}

Our independent variables include information about the Chairs and their intuitions (see Table 1). We include three measures for the Chair's research output, which is our key explanatory variable: Chair's citations represent the cumulative number of citations made to the Chair's five most highly cited articles published prior to his/her Chair appointment (measured as a citations total in the year 2012).

We also control for the number of years since each of the Chair's five most-cited papers were published (the total number of years are averaged). Finally, we include Chair's cumulative number of total weighted journal publications measured to year t. The weighted measures convert page counts to American Economic Association-equivalent pages, use the $1 / n$ rule for co-authored articles, and apply a quality indexing using the journal “Impact Factors” provided in the various annual editions of the Social Sciences Journal Citation Reports.

Further information about Chairs’ characteristics are included in the regressions: gender, whether they were foreign-born, their total experience measured as years since $\mathrm{PhD}$, the years spent at each university, the number of institutions in which he or she had worked, and Chairs' fields.

Controls for the nature of each institution are also incorporated (see Table 1). These measure the department's research output at the start of the Chair's term, the size of each department (we include a proxy for the number of economics PhDs), and the wealth of each university. To capture trends in the US academic markets for economists, we include variables that measure the Chair's institution's share of economics publications that do not go to Economics departments (i.e. business schools), and the share of top publications assigned to 
authors not affiliated with a US Economics department. Finally, we include both a set of dichotomous variables indicating the Chair's research field (i.e. microeconomics, macroeconomics, history/thought, monetary, quantitative, public finance, international, agriculture/environmental, industrial organization, labor, other), and a set of dichotomous variables indicating the calendar year (i.e. 1995, 1996, 1997 ... 2010).

(INSERT Table 3 HERE)

\section{ECONOMETRIC ANALYSIS AND RESUlts}

Summary statistics are presented in Table 3. Table 4 reports the study's key findings. Each rightward column introduces additional controls to a base specification in Column 1 that includes a quadratic in citations as well as the department's research output at the start of the chair's term. For reasons of brevity, the results are condensed into a single table (a number of alternative variants have been tested and are available upon request). Clustered standard errors are used for the reported t-statistics in parentheses.

In Model 1 of Table 4, a variable for Chair's citations is statistically significant at the 5\% level; the coefficient is 0.0001 and the t-statistic is 2.12. The coefficient on the quadratic term (of -0.0624) is negative and significant at the 5\% level. It follows that the relationship between a department's research output and a Chair's research citations is estimated to be concave from below.

(INSERT Table 4 HERE)

The curvature can be seen in Figure 1. Departmental performance, shown on the x-axis, maximizes when a Chair has approximately 9,100 citations. With a mean citation number of 
2,153 and a standard deviation is 2,873 , it is unclear how seriously this exact turning point itself should be treated as there are only 10 departmental heads who have citations in excess of 9,100 (Ioannidis, 2010). Nonetheless, the finding of some form of diminishing returns to a Chair's citations appears to be a robust statistical conclusion. ${ }^{4}$ Model 1 also suggests mild evidence that a department's research productivity may exhibit reversion to the mean. The coefficient on a department's research output at the start of a Chair's term is -0.0861 with a t-statistic of -1.86 .

(INSERT Figure 1 HERE)

A natural hypothesis is that what matters is a department head's own publishing productivity. Thus, Model 2 introduces controls for the total number of weighted publications and the timing of citations. Importantly, the magnitude, sign, and significance of both the level and quadratic terms on Chair's citations are not affected by the introduction of these controls. Moreover, the coefficient on the level and quadratic terms for the total number of weighted publications are insignificant. This finding implies that it is not the quantity of papers published by a Chair that matters but instead the extent to which the Chair's work has been recognized through cited references to his or her research. In addition, the coefficient on the average number of years since each of the Chair's most-cited papers were published is insignificant and has no effect on the link between the person's citations and the department's research productivity.

Model 3 introduces demographic attributes and other aspects of a Chair's career into the empirical specification. Again, the broad conclusions with regard to the positive and diminishing effect of a Chair's citations on department research output remain, and there is some

\footnotetext{
${ }^{4}$ We have experimented with other nonlinear functional forms.
} 
evidence that the effect actually increases in magnitude and statistical significance. The coefficient is 0.0002 , and the t-statistic is 2.89 , significant at the $1 \%$ level. In addition, now the coefficient on the number of years since the Chair's most cited work is negative and significant at the $10 \%$ level, suggesting that Chairs whose reputation is built on more recent work are relatively more effective at improving a department's productivity.

The coefficients on most of the newly introduced controls in Model 3 are insignificant at traditional levels (i.e., the controls for gender, foreign-born, Chair's years at current university, and number of institutions where Chair has worked). However, there appears to be a non-linear, statistically significant effect associated with experience, suggesting a Chair's years since PhD has a positive net effect after approximately 20.5 years of experience. In other words, all else equal, the tradition of putting more senior faculty in the position of Chair is consistent with a raising of a department's research productivity, although the impact here is smaller relative to the quality of the Chair as measured by citations.

In Model 4 we include a number of variables to control for the size of the Economics department and for university characteristics (see Table 1: Variable Definitions). In general, the conclusions drawn from the previous models are unaltered, although the mean-reversion effect related to departmental productivity increases both in magnitude and significance in the more fully specified model. Many of the newly introduced institutional variables are significant at traditional levels. Specifically, the share of publications to non-US Economics departments has a significantly negative effect; articles that are published to authors outside the US Economics departments reduce the available pool. The institution's share of Economics publications that go to faculty based in non-Economics departments (e.g., business and policy schools) in the Chair's institution is significantly positive; this result suggests a possible complementarity between productive schools that hire economists and Economics departments. The Total Economics 
PhDs granted at the Chair's university’ measures the number of Economics PhDs conferred over the years 1995-2010, which is a proxy for the size of the department. As expected, the coefficient is positive and significant, which suggests that larger departments have higher overall productivity.

The final two variables introduced in Model 4 control for university income. They use data collected from the Integrated Postsecondary Education Data System (IPEDS). The penultimate row has the total current funds in year t. This variable comprises revenues from tuition and fees, government appropriations (federal, state and local), private gifts, grants and contracts, endowment income, sales and services of educational activities, "auxiliary enterprises", hospitals, "other sources", and "independent operations". The introduction of university income into Model 4 does not alter the previous results. The insignificance of the financial variable in Model 4 suggests that change in departmental quality -- research output -- is not closely tied to aggregate university income. However, perhaps somewhat surprisingly, the Chair's university's share of Federal grants in year t is negative and marginally significant.

The four specifications in Table 4 demonstrate that the citations curve relationship is robust and economically significant. First, evidence for a longitudinal link between a Chair's citations and the later research output of the department is not strongly influenced by changes in the detailed econometric specification. Second, the last row of Table 1 presents the number of citations at which the quadratic reaches its maximum in each model. The point at which the curve turns is numerically approximately the same, at between 9100 and 9800 lifetime citations, across the four columns. If taken literally, the implied effect of Chairs is large. A one standard deviation rise in a chairperson's citations (from a base of zero citations) is associated with a later improvement of approximately one half of a standard deviation in the department's later research productivity. 
Because our study is in the spirit of Granger causality, we wish to emphasize extreme caution in causal interpretation. Nevertheless, in this important area, in which real-life decisions have necessarily to be taken every day by Deans around the world, and about which so little formal evidence exists, the patterns found in this analysis may be of practical interest and may act to spur further research.

\section{CONCLUSIONS AND DISCUSSION}

Little is known about successful leadership in the thousands of academic departments that make up universities. In what we believe is the first study of its kind, this analysis examines the statistical links between the characteristics of incoming Chairs and the later scientific productivity of their departments. It does so in the spirit of Granger causality; real life settings do not easily lend themselves to random assignment, and tools used in natural experiments such as death of a leader (e.g. Jones \& Olken, 2005) are not possible in our setting because few Chairs die in post. We therefore are careful not to give a causal interpretation to our findings. Nevertheless, the analysis shows that a longitudinal predictor of a department's future research success is the cumulative number of citations to the incoming Chair's own research (that is, the Chair's research done prior to his or her appointment as head of department). This result appears to be a robust one. It holds after controlling for a number of factors, including institutional variables such as income and federal grants, and Chairs' other characteristics, such as their gender, work experience, and publications. We have concentrated our findings into a single table (Table 4). However, a number of variants, with the same conclusion, have been tested and are

available upon request. Notably, it is the Chair's citations that seem to matter; there is no detectable effect from a Chair's publications. 
Our data do not allow us to make empirical claims about why this pattern exists; nevertheless, it is interesting to examine possible explanations by referring back to the literature.

What might be the mechanism through which Chairs influence the research output of academic departments? And how does this interact with citations to their own research? Academics who have had successful research careers may behave differently when they become department Chairs. As suggested above, our result is consistent, at a different level of aggregation, with an earlier longitudinal analysis of university presidents (Goodall, 2009a,b). McCormack, Propper \& Smith (2013) show, in UK universities, that departments which are better managed also demonstrate better performance in both research and teaching. Their finding holds across all types of universities, and because of the decentralised nature of academic institutions, they note that it is practices at the department level, not within centralised human resources, that seem to matter most. Importantly, they conclude, as we do, that the results are not driven by differences in resources.

McCormack and colleagues identify the key areas as recruitment, retention, and promotion. In interviews with university presidents (Goodall 2009a,b), it has been found that scholar-leaders may find it easier to recruit and retain other top scholars. It was argued there that this may be because of reputational factors (Hamermesh \& Pfann, 2012), or because a head who is a cited scholar signals to potential recruits that he or she understands how to create the right incentives and work environment for other research-focussed academics (Andrews \& Farris1967; Goodall, 2009a,b).

Azoulay, Zivin, \& Manso (2011) compare outputs from researchers at the Howard Hughes Medical Institute (HHMI) with those funded through the National Institute of Health (NIH). While they do not focus on leadership in these groups, they do call attention to management practices that are associated with high-impact papers. Azoulay and colleagues find 
that HHMI tolerates early failure, is prepared to reward long-term success, and gives researchers a great deal of autonomy; by contrast, recipients of funding from the NIH are exposed to shorter review cycles, and expected to produce outputs that are predefined, and early failure is tolerated less. The authors show that HHMI investigators produce more novel and more highly cited papers than the comparison group funded by NIH (Azoulay, Zivin \& Manso, 2011). Given the department Chairs' result, it would be interesting to know whether the decision-makers in the Howards Hughes Institute were themselves more cited researchers than their peers in the National Institute of Health.

The suggestion that leaders and followers should share equivalent levels of technical expertise has been examined in early cross-sectional studies (e.g. Andrews \& Farris, 1967; Barnowe, 1975; McAuley, Duberley \& Cohen, 2000; Mumford, Marks, Connelly, Zaccaro \& Reiter-Palmon, 2000). Mumford, Scott, Gaddis, \& Strange (2002) summarize these findings: they argue that technical and creative problem-solving skills are necessary when leading creative people, and that the evaluation of researchers and their ideas is best done by individuals who share their competencies. Also, leaders who have the same creative and technical abilities as their followers can communicate clearly and articulate the goals of the organization (Mumford et al., 2002).

Although this study's statistical findings will have first to be scrutinized, and replicated, in other research, they may eventually have practical implications. The findings suggest that, especially where all else is equal among contenders for the position of department Chair, universities might wish to examine whether the processes by which chairs are selected in the institution yield candidates whose research is highly cited. The issue of why it is that cited work appears to be an important signal cannot be answered by our study. It deserves to be addressed, with qualitative and quantitative methods, in future research. 


\section{References}

Adams, J. D., Black, G. C., Clemmons, J. R. \& Stephan, P. E. 2005. Scientific teams and institutional collaborations: Evidence from US universities, 1981-1999. Research Policy, 34, 259-285.

Andrews, F. 1979. Scientific Productivity: The Effectiveness of Research Groups in Six Different Countries. Cambridge University Press, Cambridge.

Andrews, F. M. \& Farris, G. F. 1967. Supervisory practices and innovation in scientific teams. Personnel Psychology, 20, 497-515.

Antonakis, J., Bendahan, S., Jacquart, P. \& Lalive, R. 2010. On making causal claims: A review and recommendations. Leadership Quarterly, 21 (6), 1086-1120.

Azoulay, P., Zivin, J. S. G. \& Manso, G. 2011. Incentives and creativity: Evidence from the academic life sciences. RAND Journal of Economics, 42 (3), 527-554.

Barnowe, J.T. 1975. Leadership and performance outcomes in research organizations. Organizational Behavior and Human Performance, 14, 264-280.

Beerkens, M. 2013. Facts and fads in academic research management: The effect of management practices on research productivity in Australia. Research Policy, 42(9), 1679-1693.

Bloom, N. \& J. Van Reenen 2007. Measuring and explaining management practices across firms and countries. Quarterly Journal of Economics, 122(4), 1351- 1408.

Blume, S.S. \& Sinclair, R. 1973. Chemists in British universities: a study of the reward system in science. American Sociological Review, 38 (1), 126-138.

Carroll, J. B., \& Wolverton, M. 2004. Who becomes a chair? New Directions for Higher Education, 126, 3-10.

Clotfelter, C. T. \& Rothschild, M. 1993. In C. T. Clotfelter \& M. Rothschild (Eds.), Studies of supply and demand in higher education (pp. 1-9). Chicago and London: The University of Chicago Press.

Conrad, P., Carr, P., Knight, S., Renfrew, M. R., Dunn, M. B., \& Pololi, L. 2010. Hierarchy as a barrier to advancement for women in academic medicine. Journal of Women's Health, 19 (4), 799-805. 
Ehrenberg, R. G. 1999. Adam Smith goes to college: An economist becomes an academic administrator. Journal of Economic Perspectives, 13 (1), 99-116.

Goodall, A. H. 2006. Should top universities be led by top researchers, and are they? A citations analysis'. Journal of Documentation, 62, 388-411.

Goodall, A. H. 2009a. Highly cited leaders and the performance of research universities. Research Policy, 38 (7), 1079-1092.

Goodall, A.H. 2009b. Socrates in the boardroom: Why research universities should be led by top scholars. Princeton University Press, Princeton and Oxford.

Hamermesh, D. S., \& Pfann, G. A. 2012. Reputation and earnings: the roles of quality and quantity in academe. Economic Inquiry, 50 (1), 1-16.

Ioannidis, J. P 2010. Is there a glass ceiling for highly cited scientists at the top of research universities? FASEB journal: Official publication of the Federation of American Societies for Experimental Biology, 24 (12).

Jones, B. F. \& Olken, B. A. 2005. Do leaders matter? National leadership and growth since World War II. Quarterly Journal of Economics, 120 (3), 835-864.

Jones, B.F., Wuchty, S., \& Uzzi, B. 2008. Multi-university research teams: shifting impact, geography, and stratification in science. Science, 284 (5905), 1259-1262.

McAuley, J. Duberley, S. \& Cohen, L. 2000. The meaning professional give to management and strategy. Human Relations, 53, 87-116.

McCormack, J., Propper , C. \& Smith, S. 2013. Herding cats? Management and university performance. Working Paper No. 13/308, Centre for Market and Public Organisation, Bristol University (June).

McDowell, J., Singell, L. D., \& Stater, M. 2009. Congratulations or condolences? The role of human capital in the cultivation of a university administrator. Economics of Education Review, 28 (2), 258-267.

McDowell, J., Singell, L., \& Stater, M. 2011. On (and off) the hot seat: An analysis of entry into and out of university administration. Industrial \& Labour Relations Review, 64 (5), 889-909.

Moore, W. J., Newman, R. J., \& Turnbull, G. K. 2003. Internal markets for department chairs: Comparative advantage, life-cycle, and jury duty. Journal of Labor Research, 24 (4), 669-682. 
Mumford, M. D., Marks, M. A., Connelly, M. S., Zaccaro, S. J., \& Reiter-Palmon, R. 2000. Development of leadership skills: experience, timing, and growth. Leadership Quarterly, 11, 87114.

Mumford, M. D., Scott, G. M., Gaddis, B., \& Strange, J. M. 2002. Leading creative people: Orchestrating expertise and relationships. Leadership Quarterly, 13(6), 705-750.

Ness, R. B. \& Samet, J. M. 2010. How to be a department chair of epidemiology: a survival guide. American Journal of Epidemiology, 172 (7), 747-51.

Pelz, D.C., 1956. Some social factors related to performance in a research organization. Administrative Science Quarterly, 3, 310-325.

Pelz, D.C., Andrews, F.M., 1966. Scientists in Organizations: Productive Climates for Research and Development. John Wiley and Sons, New York.

Van der Weijden, I., de Gilder, D., Groenewegen, P., \& Klasen, E. 2008. Implications of managerial control on performance of Dutch academic (bio)medical and health research groups. Research Policy, 37(9), 1616-1629.

Wuchty, S., Jones, B. F., \& Uzzi, B. 2007. The increasing dominance of teams in production of knowledge. Science, 316 (5827), 1036-9. 


\section{Figure 1}

The Change in Research Output of US University Departments as a Function of the Incoming Department Chair's Citations

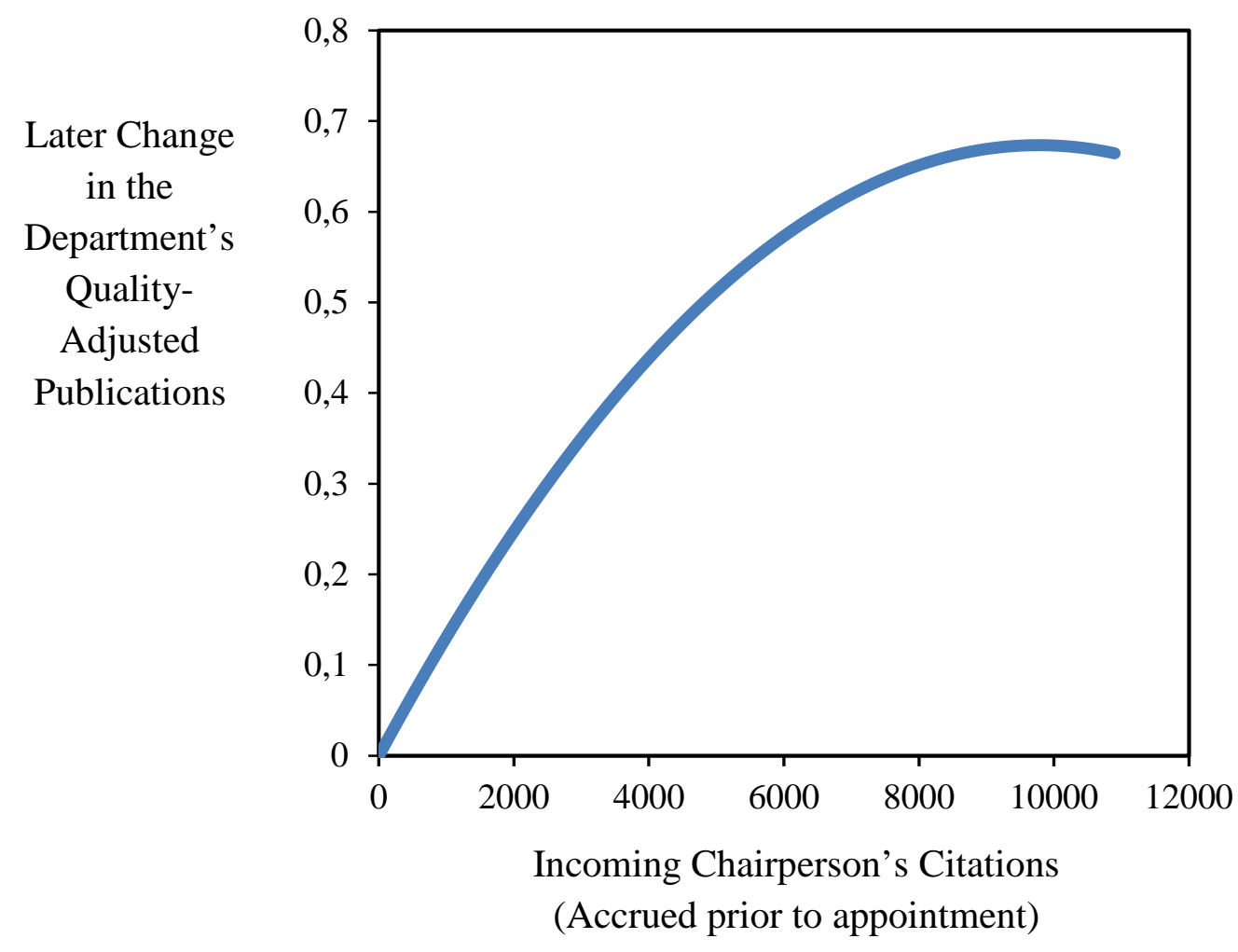

Notes: Only 10 of 169 Chairpersons had lifetime citations above the turning point of 9100 citations. This curve is based on Column 1 in Table 4 . 


\section{Table 1}

\section{Variable Definitions}

\section{Dependent Variable}

Change in department's research output: The change in a department's share of total US weighted economics publications (i.e. $1 / \mathrm{n}$ and quality index) measured between the first year $(t=0)$ of the Chair's appointment and the current year $t$, where research output in year $t$ is measured by a 3-yr moving average in years $t-1, t$, and $t+1$.

Publications data is collected annually over the years 1995 through 2010 from the following select journals: American Economic Review, Econometrica, Economic Journal, Economica, International Economic Review, Journal of Economic Theory, Journal of Monetary Economics, Journal of Political Economy, Quarterly Journal of Economics, Review of Economics and Statistics, and the Review of Economic Studies. Only data relating to full articles are collected, thus excluding comments, replies and other such shorter forms of communications.

\section{Independent Variables}

\section{(1) Chair's research output}

Chair's citations: The cumulative number of citations made to the Chair's five most highly cited articles that were published prior to his/her Chair appointment (measured in 2012).

Number of years since Chair's most cited work: The number of years since each of the Chair's five most cited papers were published; the total number of years are averaged.

Chair's total weighted publications: Chair's cumulative number of total weighted (i.e. $1 / n$ and quality index) journal publications measured to year t.

The weighted measures convert page counts to AEA-equivalent pages, use the $1 / \mathrm{n}$ rule for coauthored articles, and apply a quality indexing using the journal "Impact Factors" provided in the various annual editions of the Social Sciences Journal Citation Reports.

\section{(2) Chair Characteristics}

Female Chair: Dichotomous variable $=1$ if the Chair is female.

Foreign-born Chair: Dichotomous variable $=1$ if the Chair has a non-US birthplace.

Chair's years since PhD: The number of years since the Chair received his/her PhD.

Chair's years at university: The number of years that the Chair has worked at the university prior to his/her Chair appointment. 
Number of institutions where Chair has worked: The number of institutions the Chair has had a permanent appointment measured from the $\mathrm{PhD}$ year to the year of the Chair's appointment.

\section{(3) Institution Controls}

Department's research output at the start of the Chair's term: The department share of total weighted US economics publications in the first year of chair's term (this is an average of weighted publications in the year immediately prior to the Chair appointment, in the year of the appointment, and the first year after).

Share of world publications to non-US Economics departments: The share of all weighted publications in year t that are authored by individuals with a non-US economics department affiliation over the years 1995-2010.

Institution's share of economics publications to business and policy schools: The Chair's institution's share of all weighted publications in year t that are authored by individuals in a US non-Economics department (e.g. business schools, policy schools, etc.) over the years 19952010.

Total economics PhDs granted at Chair's university: The total number of economics PhDs granted by the Chair's university over the years 1995-2010.

University revenue: Total current fund revenues in year t (millions). This variable includes: tuition and fees, government appropriations (federal, state and local), private gifts, grants and contracts, endowment income, sales and services of educational activities, "auxiliary enterprises", hospitals, "other sources", and "independent operations". Data collected from the Integrated Postsecondary Education Data System (IPEDS).

University's share of federal grants: The Chair's university's share (\%) of the total (i.e., in sampled institutions) federal grants in year t. Data collected from the Integrated Postsecondary Education Data System (IPEDS).

\section{(4) Field dummies}

Set of dichotomous variables indicating the Chair's research field (i.e. microeconomics, macroeconomics, history/thought, monetary, quantitative, public finance, international, agriculture/environmental, industrial organization, labor, other).

\section{(5) Year dummies}

Set of dichotomous variables indicating the calendar year (i.e. 1995, 1996, 1997 ... 2010). 
Table 2

Economics Department Rankings

Economics Department Rankings based on the Mean Annual Research Output of Total Weighted Publications Authored by Individuals with an Affiliation in an Economics Department at a US University (publication counts measured over 1995-2010 in 11 select journals) ${ }^{1,2}$

Annual Research Output

In All Years 1995 through 2010

Harvard

M.I. T.

Princeton

Univ. of Calif., Berkeley

Chicago

New York University

Yale

Stanford

Northwestern

Pennsylvania

Univ. of Calif., Los Angeles

Columbia

Michigan

Univ. of Calif., San Diego

Wisconsin

Brown

Minnesota

Boston University

Maryland

Texas, Austin

Rochester

Cornell

Cal Tech

Duke

Ohio State

Dartmouth

Johns Hopkins

Carnegie-Mellon

Pittsburgh

Penn State

Illinois

Univ. of Calif., Davis

Virginia

Boston College

Georgetown

USC

Iowa

Michigan State

Univ. of Calif., Santa Barbara

\section{$\underline{\text { Rank }^{3}}$}

2

4

5

6

6
7
8

7
8

8

9
10

\section{1}

\section{2}

13

14

15

15

16

\section{8}

19

20
21

21

22

23

24

25

\section{6}

\section{7}

\section{8}

29

\section{0}

\section{1}

32

32

34

\section{5}

\section{6}

36
37

38

39

\begin{tabular}{lll}
7.72 & 1.50 & 5.22 \\
7.03 & 1.49 & 4.39 \\
5.33 & 2.06 & 2.07 \\
4.32 & 2.21 & 0.73 \\
4.23 & 1.96 & 2.09 \\
3.67 & 1.44 & 0.93 \\
3.44 & 1.44 & 1.50 \\
3.38 & 1.56 & 1.26 \\
3.25 & 1.12 & 1.60 \\
3.16 & 1.27 & 0.97 \\
2.91 & 1.09 & 1.14 \\
2.67 & 1.56 & 1.02 \\
2.17 & 0.86 & 0.76 \\
2.15 & 1.32 & 0.91 \\
2.06 & 0.97 & 1.04 \\
1.98 & 0.89 & 0.61 \\
1.74 & 1.04 & 0.59 \\
1.71 & 0.80 & 0.68 \\
1.55 & 0.97 & 0.39 \\
1.24 & 0.88 & 0.18 \\
1.24 & 0.58 & 0.41 \\
1.17 & 0.50 & 0.15 \\
1.15 & 0.75 & 0.00 \\
1.11 & 0.60 & 0.36 \\
1.11 & 0.48 & 0.28 \\
0.99 & 0.69 & 0.00 \\
0.96 & 0.55 & 0.21 \\
0.90 & 0.41 & 0.00 \\
0.90 & 0.68 & 0.09 \\
0.90 & 0.53 & 0.21 \\
0.86 & 0.61 & 0.06 \\
0.85 & 0.52 & 0.13 \\
0.83 & 0.42 & 0.12 \\
0.78 & 0.41 & 0.25 \\
0.77 & 0.56 & 0.00 \\
0.75 & 0.59 & 0.05 \\
0.71 & 0.53 & 0.00 \\
0.70 & 0.45 & 0.16 \\
0.67 & 0.53 & 0.04 \\
\hline & 21 &
\end{tabular}

Aggregate Research Output

\section{Shares in the Years}

1995-02 2003-10 Change

$\begin{array}{lllr}10.40 & 7.53 & 7.86 & 0.32 \\ 9.99 & 7.85 & 6.45 & -1.40 \\ 8.12 & 5.76 & 4.76 & -1.00 \\ 8.45 & 3.14 & 5.76 & 2.61 \\ 8.98 & 4.76 & 3.61 & -1.14 \\ 6.31 & 3.24 & 4.07 & 0.82 \\ 6.60 & 3.22 & 3.63 & 0.40 \\ 7.58 & 2.60 & 4.39 & 1.78 \\ 5.83 & 2.65 & 3.86 & 1.21 \\ 5.33 & 3.08 & 3.02 & -0.06 \\ 4.13 & 2.33 & 3.66 & 1.32 \\ 5.49 & 1.99 & 3.64 & 1.64 \\ 3.85 & 2.41 & 1.82 & -0.59 \\ 6.01 & 2.26 & 1.90 & -0.36 \\ 4.88 & 2.24 & 1.81 & -0.43 \\ 4.02 & 1.82 & 2.16 & 0.34 \\ 5.03 & 1.65 & 1.82 & 0.17 \\ 3.01 & 2.14 & 1.17 & -0.96 \\ 4.47 & 1.15 & 1.82 & 0.66 \\ 3.65 & 1.80 & 0.69 & -1.10 \\ 2.45 & 1.61 & 0.88 & -0.73 \\ 1.89 & 1.24 & 1.04 & -0.20 \\ 2.47 & 1.06 & 1.32 & 0.26 \\ 2.27 & 0.74 & 1.54 & 0.79 \\ 2.02 & 1.25 & 0.90 & -0.34 \\ 2.35 & 0.70 & 1.31 & 0.61 \\ 2.04 & 1.15 & 0.70 & -0.45 \\ 1.71 & 0.71 & 1.09 & 0.38 \\ 2.23 & 1.10 & 0.61 & -0.49 \\ 2.02 & 0.92 & 0.85 & -0.07 \\ 2.36 & 0.96 & 0.84 & -0.12 \\ 1.90 & 0.83 & 0.91 & 0.07 \\ 1.64 & 1.16 & 0.56 & -0.59 \\ 1.66 & 0.72 & 0.87 & 0.15 \\ 1.84 & 0.75 & 0.81 & 0.06 \\ 2.38 & 0.66 & 0.73 & 0.06 \\ 2.19 & 0.97 & 0.42 & -0.54 \\ 1.67 & 0.80 & 0.56 & -0.23 \\ 1.68 & 0.71 & 0.65 & -0.06\end{array}$




\begin{tabular}{lrrrrrrrr} 
Arizona State University & 40 & 0.63 & 0.52 & 0.00 & 1.51 & 0.66 & 0.74 & 0.08 \\
Washington, St. Louis & 41 & 0.53 & 0.37 & 0.00 & 1.17 & 0.46 & 0.64 & 0.18 \\
Univ. of Calif., Santa Cruz & 42 & 0.50 & 0.41 & 0.00 & 1.58 & 0.38 & 0.59 & 0.21 \\
Florida & 43 & 0.45 & 0.44 & 0.00 & 1.75 & 0.65 & 0.22 & -0.42 \\
Rutgers & 44 & 0.43 & 0.39 & 0.00 & 1.43 & 0.69 & 0.24 & -0.45 \\
Univ. of Calif., Irvine & 45 & 0.42 & 0.39 & 0.00 & 1.52 & 0.30 & 0.53 & 0.23 \\
University of Arizona & 46 & 0.41 & 0.22 & 0.00 & 0.90 & 0.44 & 0.39 & -0.05 \\
North Carolina, Chapel Hill & 47 & 0.40 & 0.43 & 0.00 & 1.58 & 0.48 & 0.29 & -0.18 \\
Vanderbilt & 48 & 0.40 & 0.20 & 0.00 & 0.79 & 0.44 & 0.36 & -0.08 \\
Texas A\&M & 49 & 0.39 & 0.46 & 0.00 & 1.71 & 0.54 & 0.23 & -0.31 \\
Houston & 50 & 0.39 & 0.28 & 0.00 & 0.89 & 0.46 & 0.30 & -0.16 \\
Rice & 51 & 0.37 & 0.37 & 0.00 & 1.15 & 0.38 & 0.28 & -0.10 \\
Washington & 52 & 0.36 & 0.39 & 0.00 & 1.25 & 0.59 & 0.14 & -0.45 \\
Purdue & 53 & 0.35 & 0.32 & 0.00 & 1.29 & 0.43 & 0.30 & -0.13 \\
Oregon & 54 & 0.33 & 0.25 & 0.00 & 0.84 & 0.39 & 0.26 & -0.12 \\
Iowa State & 55 & 0.32 & 0.28 & 0.07 & 1.23 & 0.20 & 0.49 & 0.29 \\
Colorado & 56 & 0.32 & 0.26 & 0.00 & 0.89 & 0.30 & 0.38 & 0.08 \\
Indiana & 57 & 0.30 & 0.20 & 0.00 & 0.61 & 0.39 & 0.23 & -0.16 \\
Emory & 58 & 0.25 & 0.23 & 0.00 & 0.73 & 0.19 & 0.31 & 0.12 \\
SUNY, Albany & 59 & 0.24 & 0.24 & 0.00 & 0.84 & 0.29 & 0.22 & -0.06 \\
SMU & 60 & 0.21 & 0.14 & 0.00 & 0.50 & 0.24 & 0.18 & -0.06 \\
Delaware & 61 & 0.20 & 0.41 & 0.00 & 1.66 & 0.24 & 0.11 & -0.13 \\
VPI & 62 & 0.16 & 0.20 & 0.00 & 0.58 & 0.26 & 0.05 & -0.21 \\
Notre Dame & 63 & 0.16 & 0.23 & 0.00 & 0.62 & 0.11 & 0.23 & 0.12 \\
George Mason & 64 & 0.12 & 0.29 & 0.00 & 1.14 & 0.04 & 0.24 & 0.20 \\
& & & & & & & & \\
\hline 1 Publication & & & & & & &
\end{tabular}

1 Publication data is collected annually over the years 1995 through 2010 from the following 11 selected journals: American Economic Review, Econometrica, Economic Journal, Economica, International Economic Review, Journal of Economic Theory, Journal of Monetary Economics, Journal of Political Economy, Quarterly Journal of Economics, Review of Economics and Statistics, and the Review of Economic Studies. Only data relating to full articles are collected, thus excluding comments, replies and other such shorter forms of communications.

2 The weighted measures convert page counts to AEA-equivalent pages, use the $1 / \mathrm{n}$ rule for coauthored articles, and apply a quality indexing using the journal "Impact Factors" provided in the various annual editions of the Social Sciences Journal Citation Reports.

3 To be included in these rankings, an institution's Department of Economics must have had one of the top-60 research outputs during either the 1995-2002 period or the 2003-2010 period (or both). 
Table 3

Descriptive Statistics

\begin{tabular}{|l|c|c|c|c|}
\hline & Mean & Std. Dev. & Min & Max \\
\hline Dependent Variable & & & & \\
\hline Change in department's research output: & $-9.88 \mathrm{E}^{-6}$ & 0.629 & -2.817 & 3.369 \\
\hline & & & & \\
\hline Independent Variables & & & & \\
\hline & & & & \\
\hline (1) Chair's research output & 2153.1 & 2873.3 & 10 & 17603 \\
\hline Chair's citations (to 5 most cited articles) & 12.97 & 4.79 & 2 & 33 \\
\hline Years since Chair's most cited work & 22.87 & 17.70 & 2.16 & 111.52 \\
\hline Chair's total weighted publications & & & & \\
\hline & & & & \\
\hline (2) Chair Characteristics & 0.067 & 0.250 & 0 & 1 \\
\hline Female Chair & 0.290 & 0.454 & 0 & 1 \\
\hline Foreign born Chair & 24.33 & 6.55 & 10 & 48 \\
\hline Chair's years since PhD & 14.55 & 8.61 & 0 & 42 \\
\hline Chair's years at university & 2.10 & 1.09 & 1 & 6 \\
\hline $\begin{array}{l}\text { Number of institutions where Chair has } \\
\text { worked }\end{array}$ & & & & \\
\hline & & & & \\
\hline (3) Institution Controls & 1.531 & 1.763 & 0.000 & 8.562 \\
\hline $\begin{array}{l}\text { Department's research output at the start of } \\
\text { the Chair's term }\end{array}$ & 55.08 & 2.63 & 50.93 & 61.19 \\
\hline $\begin{array}{l}\text { Share of world publications to non-US } \\
\text { Economics departments (\%) }\end{array}$ & 1.73 & 3.08 & 0 & 14.48 \\
\hline $\begin{array}{l}\text { Institution's share of economics } \\
\text { publications to business and policy schools } \\
\text { (\%) }\end{array}$ & 208.5 & 124.4 & 42 & 555 \\
\hline $\begin{array}{l}\text { Total economics PhDs granted at Chair's } \\
\text { university }\end{array}$ & 18.311 & 13.654 & 1.002 & 101.599 \\
\hline University revenue (100 millions) & 1.64 & 1.13 & 0.06 & 5.72 \\
\hline University's share of federal grants (\%) & & & & \\
\hline & & & & 1 \\
\hline (4) Field Dummies & 0.158 & 0.365 & 0 & 1 \\
\hline Microeconomics & 0.108 & 0.310 & 0 & 1 \\
\hline Macroeconomics & 0.044 & 0.204 & 0 & 1 \\
\hline History/Thought & 0.102 & 0.303 & 0 & 1 \\
\hline Quantitative & 0.121 & 0.217 & 0 & 1 \\
\hline Public Finance & 0.093 & 0.329 & 0 & 1 \\
\hline Monetary & 0.040 & 0.196 & 0 & 1 \\
\hline International & 0.080 & 0.271 & 0 & 1 \\
\hline Agriculture/Environment & 0.168 & 0.375 & 0 & 1 \\
\hline Industrial Organization & 0.036 & 0.187 & 0 & 1 \\
\hline Labor & 0.019 & 0.138 & 0 & \\
\hline Other & 0.035 & 0.184 & 0 & \\
\hline (5) Time Dummies & & & \\
\hline 1996 & & & & \\
\hline 1997 & & & & \\
\hline
\end{tabular}




\begin{tabular}{|l|l|l|l|l|}
\hline 1998 & 0.052 & 0.222 & 0 & 1 \\
\hline 1999 & 0.063 & 0.243 & 0 & 1 \\
\hline 2000 & 0.068 & 0.252 & 0 & 1 \\
\hline 2001 & 0.078 & 0.270 & 0 & 1 \\
\hline 2002 & 0.081 & 0.272 & 0 & 1 \\
\hline 2003 & 0.082 & 0.275 & 0 & 1 \\
\hline 2004 & 0.079 & 0.270 & 0 & 1 \\
\hline 2005 & 0.075 & 0.264 & 0 & 1 \\
\hline 2006 & 0.084 & 0.277 & 0 & 1 \\
\hline 2007 & 0.088 & 0.284 & 0 & 1 \\
\hline 2008 & 0.076 & 0.266 & 0 & 1 \\
\hline 2009 & 0.067 & 0.250 & 0 & 1 \\
\hline 2010 & 0.051 & 0.220 & 0 & 1 \\
\hline
\end{tabular}


Table 4

\section{Regression Equations for the Later Improvement in Department Research Performance}

(The dependent variable is the change in a department's research output measured between the first year of the incoming Chair's appointment and the current observed year. Research output of a department is measured by a 3-yr moving average of quality-weighted publications)

\begin{tabular}{|c|c|c|c|c|}
\hline Explanatory variable & Model 1 & Model 2 & Model 3 & Model 4 \\
\hline Chair's citations & $\begin{array}{l}0.0001^{* *} \\
(2.12)\end{array}$ & $\begin{array}{l}0.0001^{* *} \\
(2.28)\end{array}$ & $\begin{array}{l}0.0002 * * * \\
(2.89)\end{array}$ & $\begin{array}{l}0.0001^{* * *} \\
(2.82)\end{array}$ \\
\hline $\begin{array}{l}\text { Chair's citations squared } \\
\text { (scaled by } 10 \text { million) }\end{array}$ & $\begin{array}{c}-0.0624 * * \\
(-1.96)\end{array}$ & $\begin{array}{c}-0.0671 * * \\
(-2.11)\end{array}$ & $\begin{array}{c}-0.0851 * * * \\
(-2.57)\end{array}$ & $\begin{array}{c}-0.0705^{* * *} \\
(-2.86)\end{array}$ \\
\hline $\begin{array}{l}\text { Department's research output at the } \\
\text { start of the Chair's term }\end{array}$ & $\begin{array}{c}-0.0861^{*} \\
(-1.86)\end{array}$ & $\begin{array}{c}-0.0873^{*} \\
(-1.90)\end{array}$ & $\begin{array}{c}-0.0726^{*} \\
(-1.70)\end{array}$ & $\begin{array}{c}-0.2331^{* * *} \\
(-5.61)\end{array}$ \\
\hline $\begin{array}{l}\text { Number of years since Chair's } \\
\text { most cited work }\end{array}$ & & $\begin{array}{l}-0.0080 \\
(-0.68)\end{array}$ & $\begin{array}{c}-0.0253 * \\
(-1.71)\end{array}$ & $\begin{array}{c}-0.0205^{*} \\
(-1.72)\end{array}$ \\
\hline Chair's total weighted publications & & $\begin{array}{c}-0.0058 \\
(-0.73)\end{array}$ & $\begin{array}{l}-0.0087 \\
(-1.12)\end{array}$ & $\begin{array}{c}-0.0083 \\
(-1.07)\end{array}$ \\
\hline $\begin{array}{l}\text { Chair's total weighted } \\
\text { publications squared }\end{array}$ & & $\begin{array}{l}0.0001 \\
(0.71)\end{array}$ & $\begin{array}{l}0.0001 \\
(0.71)\end{array}$ & $\begin{array}{l}0.0000 \\
(1.03)\end{array}$ \\
\hline Female Chair & & & $\begin{array}{l}0.1348 \\
(0.82)\end{array}$ & $\begin{array}{l}0.1337 \\
(0.86)\end{array}$ \\
\hline Foreign-born Chair & & & $\begin{array}{l}0.0085 \\
(0.10)\end{array}$ & $\begin{array}{l}0.0023 \\
(0.03)\end{array}$ \\
\hline Chair's years since $\mathrm{PhD}$ & & & $\begin{array}{c}-0.0655^{* *} \\
(-1.94)\end{array}$ & $\begin{array}{l}-0.0436 \\
(-1.59)\end{array}$ \\
\hline Chair's years since $\mathrm{PhD}$ squared & & & $\begin{array}{c}0.0016 * * * \\
(2.52) \\
\end{array}$ & $\begin{array}{c}0.0011^{* *} \\
(2.02) \\
\end{array}$ \\
\hline Chair's years at current university & & & $\begin{array}{l}0.0048 \\
(0.67)\end{array}$ & $\begin{array}{l}0.0037 \\
(0.55)\end{array}$ \\
\hline $\begin{array}{l}\text { Number of institutions where } \\
\text { Chair has worked }\end{array}$ & & & $\begin{array}{l}0.0667 \\
(1.07)\end{array}$ & $\begin{array}{l}0.0589 \\
(1.07)\end{array}$ \\
\hline $\begin{array}{l}\text { Share of world publications to non- } \\
\text { US Economics departments }\end{array}$ & & & & $\begin{array}{c}-0.1520 * * \\
(-2.45)\end{array}$ \\
\hline $\begin{array}{l}\text { Institution's share of publications to } \\
\text { business and policy schools }\end{array}$ & & & & $\begin{array}{c}0.0533^{* *} \\
(2.14)\end{array}$ \\
\hline $\begin{array}{l}\text { Total economics PhDs granted at the } \\
\text { Chair's university }\end{array}$ & & & & $\begin{array}{c}0.0014^{* * *} \\
(2.64)\end{array}$ \\
\hline University revenue $^{a}$ & & & & $\begin{array}{l}0.0057 \\
(1.51)\end{array}$ \\
\hline University’s share of federal grants & & & & $\begin{array}{c}-0.0636 * \\
(-1.68)\end{array}$ \\
\hline
\end{tabular}




\begin{tabular}{|c|c|c|c|c|}
\hline FIELD DUMMIES & YES & YES & YES & YES \\
\hline YEAR DUMMIES & YES & YES & YES & YES \\
\hline $\mathrm{R}^{2}$ & 0.075 & 0.081 & 0.126 & 0.224 \\
\hline $\begin{array}{c}\text { Citations number at which the } \\
\text { quadratic reaches its maximum }\end{array}$ & 9,094 & 9,389 & 9,194 & 9,773 \\
\hline
\end{tabular}

$\mathrm{n}=825 ; \quad * * *$ - significant at 0.01 level; ** - significant at 0.05 level; * - significant at 0.10 level;

Clustered t-statistics in parentheses.

Field dummies are dummy variables for the Chair's sub-specialty.

a If we instead use the 'change in revenue' in the model, the financial variable remains statistically insignificant. This variable includes revenues from tuition and fees, government appropriations (federal, state and local), private gifts, grants and contracts, endowment income, sales and services of educational activities, "auxiliary enterprises", hospitals, "other sources", and "independent operations".

The mean of Chairs' citations is 2153.1; the standard deviation is 2873.3; the minimum is 10; the maximum is 17603. 